\title{
Article \\ Crypthecodinium cohnii Growth and Omega Fatty Acid Production in Mediums Supplemented with Extract from Recycled Biomass
}

\author{
Elina Didrihsone ${ }^{1, *}$, Konstantins Dubencovs ${ }^{1,2,3}$, Mara Grube ${ }^{4}$, Karlis Shvirksts ${ }^{4}$, Anastasija Suleiko ${ }^{1}$, \\ Arturs Suleiko $^{1,2}$ and Juris Vanags ${ }^{1,2,3}$
}

Citation: Didrihsone, E.;

Dubencovs, K.; Grube, M.;

Shvirksts, K.; Suleiko, A.; Suleiko, A.;

Vanags, J. Crypthecodinium cohnii Growth and Omega Fatty Acid Production in Mediums

Supplemented with Extract from Recycled Biomass. Mar. Drugs 2022, 20,68. https://doi.org/10.3390/ md20010068

Academic Editors: Maria do Rosário Domingues and Philippe Soudant

Received: 19 December 2021

Accepted: 7 January 2022

Published: 12 January 2022

Publisher's Note: MDPI stays neutral with regard to jurisdictional claims in published maps and institutional affiliations.

Copyright: (C) 2022 by the authors. Licensee MDPI, Basel, Switzerland. This article is an open access article distributed under the terms and conditions of the Creative Commons Attribution (CC BY) license (https:// creativecommons.org/licenses/by/ $4.0 /)$.
1 Latvian State Institute of Wood Chemistry, LV1006 Riga, Latvia; gmtd@inbox.lv (K.D.); anastasija.gurcinska@gmail.com (A.S.); arturs.suleiko@bioreactors.net (A.S.); btc@edi.lv (J.V.)

2 A/S Biotehniskais Centrs, LV1006 Riga, Latvia

3 Institute of General Chemical Engineering, Faculty of Materials Science and Applied Chemistry, Riga Technical University, LV1048 Riga, Latvia

4 Institute of Microbiology and Biotechnology, University of Latvia, LV1004 Riga, Latvia; mara.grube@lu.lv (M.G.); karlis.svirksts@lu.lv (K.S.)

* Correspondence: elina.didrihsone@kki.lv

\begin{abstract}
Crypthecodinium cohnii is a marine heterotrophic dinoflagellate that can accumulate high amounts of omega-3 polyunsaturated fatty acids (PUFAs), and thus has the potential to replace conventional PUFAs production with eco-friendlier technology. So far, C. cohnii cultivation has been mainly carried out with the use of yeast extract (YE) as a nitrogen source. In the present study, alternative carbon and nitrogen sources were studied: the extraction ethanol (EE), remaining after lipid extraction, as a carbon source, and dinoflagellate extract (DE) from recycled algae biomass C. cohnii as a source of carbon, nitrogen, and vitamins. In mediums with glucose and DE, the highest specific biomass growth rate reached a maximum of $1.012 \mathrm{~h}^{-1}$, while the biomass yield from substrate reached $0.601 \mathrm{~g} \cdot \mathrm{g}^{-1}$. EE as the carbon source, in comparison to pure ethanol, showed good results in terms of stimulating the biomass growth rate (an 18.5\% increase in specific biomass growth rate was observed). DE supplement to the EE-based mediums promoted both the biomass growth (the specific growth rate reached $\left.0.701 \mathrm{~h}^{-1}\right)$ and yield from the substrate $\left(0.234 \mathrm{~g} \cdot \mathrm{g}^{-1}\right)$. The FTIR spectroscopy data showed that mediums supplemented with EE or DE promoted the accumulation of PUFAs/docosahexaenoic acid (DHA), when compared to mediums containing glucose and commercial YE.
\end{abstract}

Keywords: Crypthecodinium cohnii; omega-3 fatty acid; biomass recycling; dinoflagellate extract; FTIR spectroscopy

\section{Introduction}

One of the most commercially important representatives of the omega-3 fatty acids' (FAs) group is docosahexaenoic acid (DHA), which is a long-chain, highly polyunsaturated omega-3 (n-3) fatty acid (LC-PUFA). DHA is considered one of the most significant and beneficial fatty acids for the health of infants and adults. Numerous research papers have reported that DHA supports the human cardiovascular and nervous systems, prevents the occurrence of inflammatory diseases, alleviates depression, and treats psoriasis and rheumatoid arthritis. Furthermore, DHA plays a key role in the healthy development of the fetal brain and retina, thus it is commonly included in infant-oriented food products and supplements [1,2].

Currently, the main source of DHA is fish oil. However, when compared to microbial DHA, fish-derived PUFAs lack the flexibility of its biosynthetic counterpart, as availability of raw materials (e.g., fish oil for its production) strongly depends on fish resources (e.g., 
seasonality and geographical location). The fish oil purification process is also quite difficult, and the resulting product remains unsuitable for all dietary requirements (e.g., vegetarians and vegans) [3-5]. Furthermore, fish oil has a specific odour and taste, which is unpleasant for a noticeable part of people, especially infants. Therefore, omega-3 FA obtainment from fish is suboptimal and poses a negative effect on the environment. Moreover, conventional DHA production currently cannot meet the increasing demand for omega-3 FA for human consumption [5].

A wide misconception is that fish produce DHA themselves through specific metabolic pathways, which are semi-unique to aquatic life forms. Marine organisms, especially different families of fish, in their natural habitats accumulate omega-3 FAs in their organisms through feeding on zooplankton, which in turn consumes the primary omega-3 FAs producers, namely microalgae [2]. However, in fish farms, the use of eicosapentaenoic acid (EPA) and DHA as feed supplements has become a conventional practice. The demand for products containing omega-3 FA has significantly increased during the past decades. However, due to insufficient fish resources, the global market currently is in crisis. As of now, the global fish oil production reaches approximately 1 million metric tonnes per year, of which $\sim 70 \%$ is generally used for aquafeeds [6].

Considering all of the above mentioned, direct methods for FAs acquisition from unicellular microorganisms, which have the ability to synthesize DHA on their own, becomes preferable, even though the cost of edible microbial oil is estimated to reach 3000-5000 USD per kg [7], which is considerably higher than conventional fish oil, estimated to exceed 2000 USD per metric ton [6]. Besides, the concentration of DHA in single cell oil (SCO), for example, from Crypthecodinium cohnii, can reach much higher concentrations when compared to fish oil (54\% and $12 \%$ by mass, respectively) [8,9].

Cultivated microalgae-derived oil does not contain heavy metals and cholesterol, and has a neutral taste, which can be easily enhanced depending on the consumer requirements [2]. The average lipid content in microalgae biomass is from 20 to $50 \%$ by mass. However, under stress conditions, it can reach even higher levels (up to 85\%) [10]. Microalgae species such as C. cohnii, Nannochloropsis gaditana, Isochrysis galbana and Phaeodactylum tricornutum were proven to be suitable for production of PUFAs on a commercial scale [10]. Multiple commercial scale applications were already previously studied and successfully put into commission (e.g., microalgae cultivation in tubular and flat panel bioreactors [10] and transgenic oilseed plants [11]), which indicates the severity of the DHA shortage that the world is experiencing right now.

A marine dinoflagellate C. cohnii can accumulate PUFAs in significant amounts (up to $25 \%$ of DHA or $35 \%$ of FAs of dry weight $[2,8]$ ) and therefore it has been used previously for industrial production of omega-3 fatty acids [12]. However, in C. cohnii cultivation processes, yeast extract (YE) is conventionally used as the nitrogen source, which noticeably affects the cost of the target products [3]. Therefore, the identification of a cheap and renewable substrate for a highly efficient DHA production by C. cohnii is necessary. In the literature, suitable carbon sources have been widely studied (e.g., glucose, acetate, glycerol, oleic acid, acetic acid, ethanol, rapeseed meal hydrolysate, crude waste molasses, cheese whey, corn steep liquor, tagatose, carob syrup, date syrup, and galacturonic acid) [3,4,13-16]. The results (see Table 1) show that the highest biomass concentrations were achieved using acetic acid and ethanol in fed-batch fermentations $\left(109 \mathrm{~g} \cdot \mathrm{L}^{-1}\right.$ and $83 \mathrm{~g} \cdot \mathrm{L}^{-1}$, respectively $\left.[17,18]\right)$ and in batch fermentations with glucose and acetate $\left(27.7 \mathrm{~g} \cdot \mathrm{L}^{-1}\right.$ and $7.03 \mathrm{~g} \cdot \mathrm{L}^{-1}$, respectively $\left.[4,19]\right)$. The highest DHA concentrations $19 \mathrm{~g} \cdot \mathrm{L}^{-1}$ and $11.7 \mathrm{~g} \cdot \mathrm{L}^{-1}$ were achieved using acetic acid and ethanol, respectively, as carbon sources in fed-batch fermentations $[17,18]$. In batch fermentations, the highest DHA titres have been achieved with glucose $\left(1.6 \mathrm{~g} \cdot \mathrm{L}^{-1}\right.$ and $\left.1.4 \mathrm{~g} \cdot \mathrm{L}^{-1}\right)[19,20]$. However, the effect of nitrogen sources on the cultivation efficiency 
has not been studied as extensively as carbon sources. Suitable nitrogen sources for marine protists are tryptone, yeast extract, peptone, soy peptone, urea, monosodium glutamate, nitrate, ammonia, and ammonium chloride [3,13]. It also should be noted that some marine protists (e.g., Schizochytrium species) can utilize a wider range of nitrogen sources than others (e.g., Crypthecodinium species) [13]. Although nitrogen source variation in C. cohnii cultivations has been employed, e.g., urea, yeast extract, meat extract, glutamic acid, ammonium sulphate, ammonium bicarbonate, sodium nitrite, and ammonium nitrate $[15,21,22]$, yet mostly the effect of the nitrogen source on the C. cohnii growth has not been the focus of the past studies. The highest DHA titres in microalgae cells $-0.99 \mathrm{~g} \cdot \mathrm{L}^{-1}$, has been observed when sodium nitrate was utilized [22]. The highest total lipid content, $28.48 \%, 18.67 \%$, and $18.14 \%$ of dry cell weight (DCW), has been observed utilizing threonine, yeast extract, and sodium nitrate, respectively [21-23]. Moreover, to the authors' knowledge, there have been no attempts to use a recycled waste product as a nitrogen source as it will be outlined in the present study.

Table 1. C. cohnii growth parameters, DHA, and lipid production with different carbon and nitrogen sources.

\begin{tabular}{|c|c|c|c|c|c|c|c|c|}
\hline Carbon Source & $\begin{array}{c}\text { Nitrogen } \\
\text { Source }\end{array}$ & $\begin{array}{l}\text { Fermentation } \\
\text { Mode }\end{array}$ & $\mu_{\max }, \mathrm{h}^{-1}$ & $\begin{array}{c}\text { Biomass, } \\
\mathrm{g} \cdot \mathrm{L}^{-1}\end{array}$ & $Y_{x / s}, g \cdot g^{-1}$ & DHA, $g \cdot L^{-1}$ & $\begin{array}{l}\text { Lipid,\% of } \\
\text { DCW }\end{array}$ & Ref. \\
\hline \multirow{3}{*}{ Acetate } & $\begin{array}{l}\text { Ammonium } \\
\text { sulphate* }\end{array}$ & \multirow{3}{*}{ Batch } & - & $\sim 7.7$ & - & - & - & \multirow{2}{*}{ [21] } \\
\hline & \multirow{2}{*}{ Yeast extract * } & & - & $\sim 6.0$ & - & - & $18.67^{* *}$ & \\
\hline & & & 0.025 & 7.03 & - & $0.03118 \pm 0.00160$ & $12.43 \pm 0.62$ & [4] \\
\hline \multirow{3}{*}{ Acetic acid } & $\begin{array}{l}\text { Ammonium } \\
\text { sulphate * }\end{array}$ & \multirow{3}{*}{ Fed-batch } & - & - & - & 0.1016 & - & \multirow[t]{2}{*}{ [21] } \\
\hline & \multirow{2}{*}{ Yeast extract * } & & - & - & - & 0.1629 & - & \\
\hline & & & 0.053 & 109 & 0.13 & 19 & $55.69 * *$ & [17] \\
\hline Ethanol & Yeast extract & Fed-batch & 0.05 & 83 & 0.31 & 11.7 & $42.17^{\text {** }}$ & [18] \\
\hline $\begin{array}{l}\text { Galacturonic } \\
\text { acid }\end{array}$ & Yeast extract & Batch & - & $3.07 \pm 0.04$ & - & $0.05273 \pm 0.00015$ & $46.58^{* *}$ & [16] \\
\hline \multirow{6}{*}{ Glucose } & $\begin{array}{l}\text { Sodium } \\
\text { nitrate * }\end{array}$ & \multirow{6}{*}{ Batch } & - & $23.7 \pm 0.61$ & 0.38 & 0.99 & $18.14^{* *}$ & [22] \\
\hline & Threonine * & & - & 25.3 & $0.95 \pm 0.09$ & - & $28.46^{* *}$ & [23] \\
\hline & $\begin{array}{l}\text { Yeast extract, } \\
\text { tryptone }\end{array}$ & & 0.067 & 2.046 & 0.499 & 0.159 & - & [24] \\
\hline & \multirow{3}{*}{ Yeast extract } & & 0.017 & 2.66 & - & $0.01634 \pm 0.00168$ & $14.70 \pm 0.07$ & [4] \\
\hline & & & - & 6.4 & - & 1.4 & - & [20] \\
\hline & & & - & 27.7 & - & 1.6 & 13.36 & [19] \\
\hline $\begin{array}{l}\text { Glycerol } \\
\text { (crude) }\end{array}$ & Yeast extract & Batch & 0.018 & 5.05 & - & $0.02696 \pm 0.00107$ & $14.70 \pm 0.73$ & \multirow{3}{*}{ [4] } \\
\hline Glycerol (pure) & Yeast extract & Batch & 0.019 & 6.33 & - & $0.01307 \pm 0.00072$ & $11.04 \pm 0.50$ & \\
\hline Molasses & Yeast extract & Batch & 0.013 & 3.91 & - & $0.01956 \pm 0.00100$ & $11.12 \pm 0.56$ & \\
\hline $\begin{array}{c}\text { Molasses } \\
\text { (crude waste) }\end{array}$ & $\begin{array}{c}\text { Rapeseed meal } \\
\text { hydrolysate }\end{array}$ & Batch & - & 3.43 & - & 0.00872 & - & [25] \\
\hline $\begin{array}{l}\text { Organosolv } \\
\text { pulps }\end{array}$ & Yeast extract & Batch & - & 5.2 & - & 0.8 & - & [20] \\
\hline
\end{tabular}

Where $\mu_{\max }$ is the specific biomass growth rate and $Y_{x / s}$ is the biomass yield from a substrate (carbon source), * The focus of the study is an effect of nitrogen source on C. cohnii growth parameters; ${ }^{* *}$ Recalculated values of the results available in the literature. 
An alternative way of cultivation could be to use the extraction ethanol (EE), remaining after lipid extraction, as a source of carbon, and extracts from recycled dinoflagellate biomass as a source of carbon, nitrogen, and vitamins. A substitute of conventional nitrogen sources, dinoflagellate extract (DE), is obtained from de-oiled microalgae biomass (i.e., after lipid extraction, by hydrolysis, neutralization with calcium carbonate, sedimentation, separation, evaporation of liquid phase, and drying). The described process can also be called biomass recycling.

The aim of the present study was to evaluate the growth and metabolic response of C. cohnii to different carbon and nitrogen sources in growth media including conventional commercially available YE, and two novel extracts (EE, Des). This approach provides more efficient use of the lipid extraction by-products/waste products and circular DHA production process (Scheme 1), and therefore could be beneficial to the bio-economy.

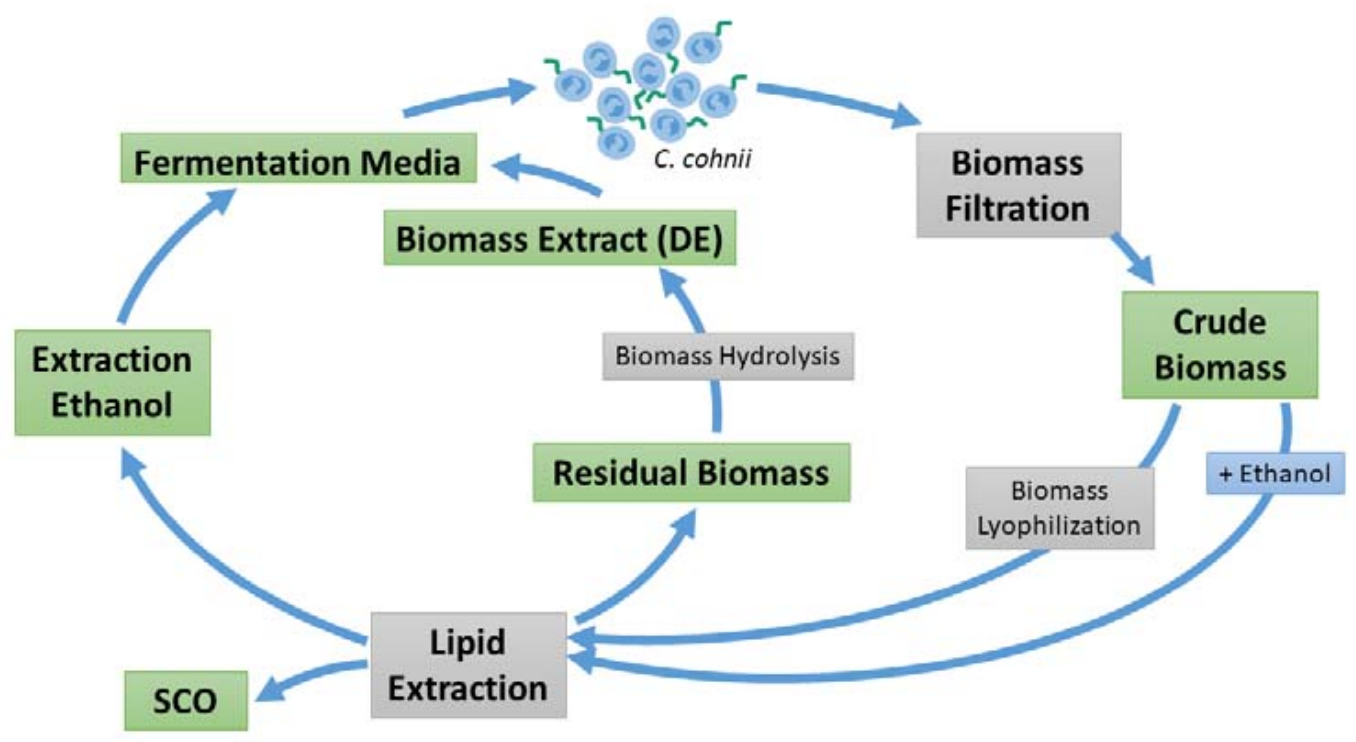

Scheme 1. Dinoflagellate extract (DE) and single cell oil (SCO) acquisition process.

\section{Results}

To access the possibility of replacing YE with cheaper alternative sources of nitrogen and nutrients for the cultivation of $C$. cohnii and DHA production, we used extracts obtained from de-oiled dinoflagellate biomass, as well as ethanol, which was used as part of one of the oil extraction methods. Two main methods were used to extract oil from the dinoflagellate biomass (see Scheme 2). In the first case, the oil was extracted from lyophilized biomass using hexane. Thus, obtaining a SCO, which after esterification can be separated into FAs. A waste product of this process is de-oiled microalgae biomass, which is hydrolysed to obtain dinoflagellate extract (DE) (see Scheme 2A). In the second case, the oil extraction is carried out through saponification of fats in wet biomass with $\mathrm{KOH}$ in the presence of ethanol. Thus, obtaining the hydroalcoholic phase, containing soaps, and de-oiled microalgae biomass. Ethanol, which is used in this process, extracts multiple components from the biomass and can serve as a source of carbon and organic nitrogen, vitamins, nutrients, and salts for subsequent cultivations (see Scheme 2B).

The first method requires additional biomass processing before the oil extraction (e.g., freezing and drying (lyophilization). On the contrary, the second method requires an additional extraction step. The obtained DEs by the first and second method were called $\mathrm{DE}_{\mathrm{A}}$ and $\mathrm{DE}_{\mathrm{B}}$, respectively. Experiments on the effect of the DE on the growth of C. cohnii were carried out in mediums with glucose as the main carbon source. EE was used as an alternative source of carbon. 

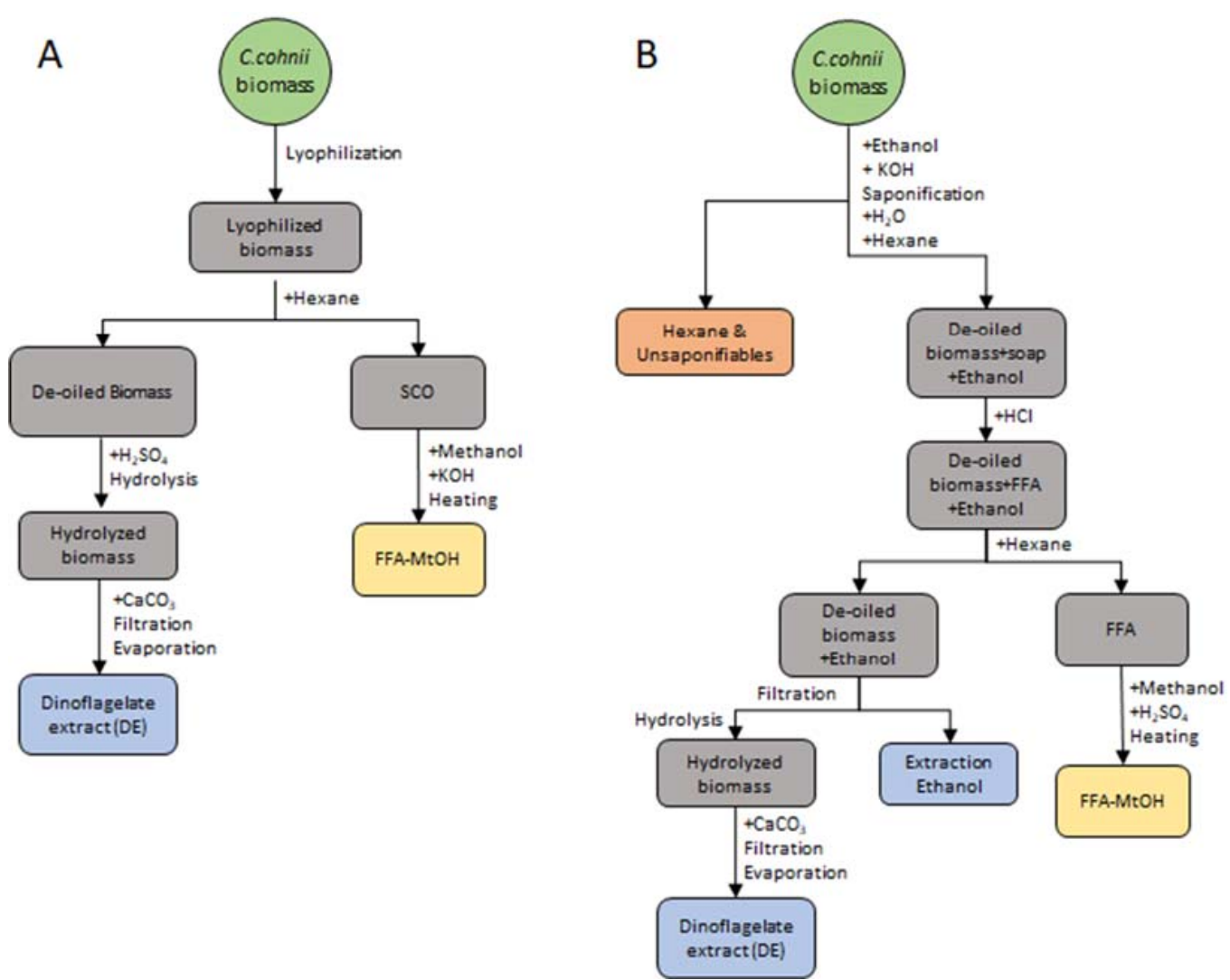

Scheme 2. Dinoflagellate extract, extraction ethanol, and free fatty acid (FFA) methyl ester acquisition from (A) lyophilized biomass and (B) wet biomass.

\subsection{Experiments with Glucose as the Carbon Source}

Multiple cultivation experiments were carried out using a complex medium containing glucose, sea salt, and YE and/or DE to study the effect of DE on the growth rate, biomass, and lipids including DHA by C. cohnii. The media composition used in the experiments with glucose as the main carbon source are summarized in Table 2. The mediums under study contained either only YE, only DE, or YE and DE (25/75 $w / w)$. Selection of the initial glucose concentration $\left(10 \mathrm{~g} \cdot \mathrm{L}^{-1}\right)$ is justified by the fact that the mentioned amount of substrate is enough for the biomass to fully consume $1 \mathrm{~g} \cdot \mathrm{L}^{-1}$ of YE. Furthermore, de Swaaf et al. [17], Jiang et al. [26], and Diao et al. [27], as part of previously reported studies, have shown that the maximum biomass growth rate is achieved if the glucose concentration is maintained in the range of $5-25 \mathrm{~g} \cdot \mathrm{L}^{-1}$. Additionally, de Swaaf et al. has demonstrated, that biomass growth inhibition begins at glucose concentrations of $20-25 \mathrm{~g} \cdot \mathrm{L}^{-1}$. The specific biomass growth rates and yields in different mediums are shown in Table 2. The maximum specific biomass growth rate and yield from glucose were observed in the medium containing exclusively $\mathrm{DE}_{\mathrm{A}}$, and were equal to 1.012 and $0.601 \mathrm{~g} \cdot \mathrm{g}^{-1}$, respectively. The lowest specific growth rate $\left(0.655 \mathrm{~h}^{-1}\right)$ was observed with the medium, which contained only $\mathrm{DE}_{\mathrm{B}}$. A similar growth rate $\left(0.615 \mathrm{~h}^{-1}\right)$ was observed with the reference medium with no added extracts.

The addition of $25 \% \mathrm{YE}$ to $75 \% \mathrm{DE}_{\mathrm{B}}$ into the cultivation medium $\left(\mathrm{DE}_{\mathrm{B} 75}\right)$ increased the specific biomass growth rate by $37 \%$ (up to $0.901 \mathrm{~h}^{-1}$ ), while the yield of biomass remained mostly unchanged $\left(0.398 \mathrm{~g} \cdot \mathrm{g}^{-1}\right)$. However, the addition of $25 \%$ of $\mathrm{YE}$ to $\mathrm{DE}_{\mathrm{A}}$ (medium $\mathrm{DE}_{\mathrm{A} 75}$ ) lowered the specific biomass growth rate to $0.9 \mathrm{~h}^{-1}$, in comparison to the mediums containing only DE extracts. 
Table 2. The medium compositions and the growth parameters of C. cohnii with glucose as carbon source.

\begin{tabular}{|c|c|c|c|c|c|c|c|}
\hline \multirow{2}{*}{ Medium } & \multicolumn{5}{|c|}{ Component, $g \cdot \mathrm{L}^{-1}$} & \multirow{2}{*}{$\mu_{h^{-1}}$} & \multirow{2}{*}{$\begin{array}{r}Y_{x / s} \\
g^{\prime} \cdot g^{-1}\end{array}$} \\
\hline & Sea Salts & Glucose & YE & $\mathrm{DE}_{\mathrm{A}}$ & $\mathrm{DE}_{\mathrm{B}}$ & & \\
\hline YE & 12.5 & 10.0 & 1.0 & - & - & 0.930 & 0.446 \\
\hline $\mathrm{DE}_{\mathrm{A}}$ & 12.5 & 10.0 & - & 1.0 & - & 1.012 & 0.601 \\
\hline $\mathrm{DE}_{\mathrm{B}}$ & 12.5 & 10.0 & - & - & 1.0 & 0.655 & 0.398 \\
\hline $\mathrm{DE}_{\mathrm{A} 75}$ & 12.5 & 10.0 & 0.25 & 0.75 & - & 0.900 & 0.403 \\
\hline $\mathrm{DE}_{\mathrm{B} 75}$ & 12.5 & 10.0 & 0.25 & - & 0.75 & 0.901 & 0.371 \\
\hline Glucose & 12.5 & 10.0 & - & - & - & 0.615 & 0.397 \\
\hline
\end{tabular}

Where $\mu_{\max }$ is the specific biomass growth rate and $\mathrm{Y}_{\mathrm{x} / \mathrm{s}}$ is the biomass yield from a substrate.

Figure 1 shows the biomass growth (A) and glucose consumption (B) curves in mediums given in Table 2. It can be seen that all mediums containing YE ensured complete assimilation of glucose in 7-14 days, while in mediums containing DE, only half of the initially supplemented substrate was assimilated until the 14th experiment day.
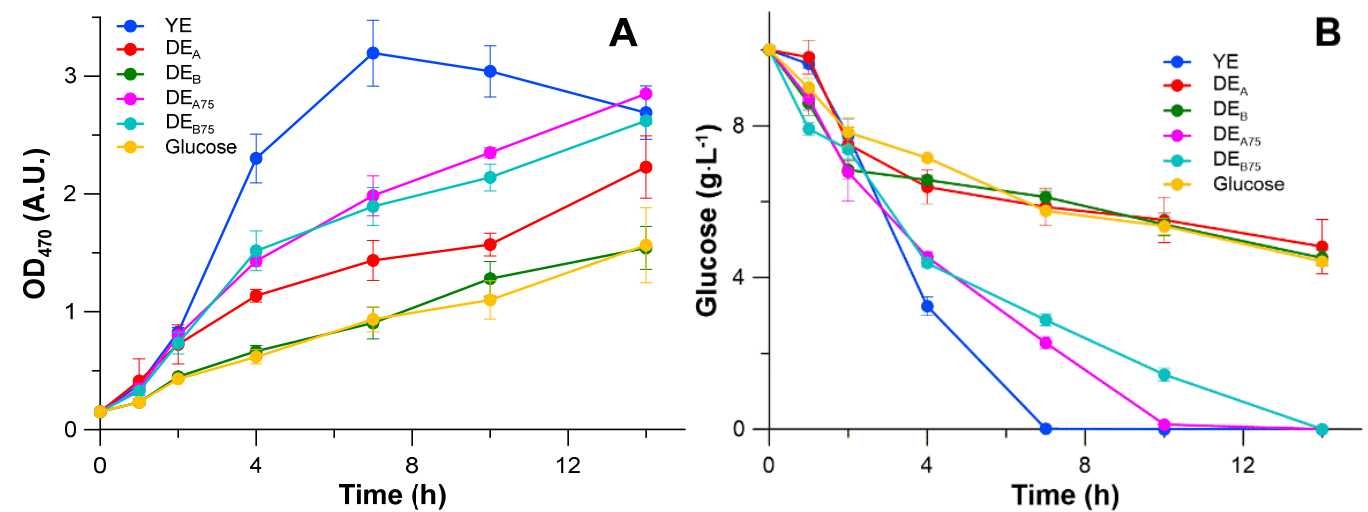

Figure 1. Cultivation of $C$. cohnii with glucose as a carbon source-(A) optical density (OD) change over time and (B) glucose concentration change over time.

Almost all growth curves, except the $\mathrm{DE}_{\mathrm{A}}$ medium, reached the lag phase during the first day of cultivation. The medium containing only YE showed the highest average specific growth rate for the first three days until all glucose was consumed. After that, the growth passed into the stationary phase and cyst formation began. In other mediums, the maximum specific growth rate was observed only on the first cultivation day, after which the biomass growth remained constant.

\subsection{Experiments with Ethanol as the Carbon Source}

The EE, collected after the lipid extraction from C. cohnii biomass, was used as the main carbon source in complex mediums containing $\mathrm{YE}$ and $\mathrm{DE}$ as sources of nitrogen and nutrients. The media compositions, the specific biomass growth rates, and biomass yields are summarized in Table 3.

The highest specific growth rate and biomass yield were obtained in mediums containing YE and reached $0.757 \mathrm{~h}^{-1}$ and $0.282 \mathrm{~g} \cdot \mathrm{g}^{-1}$, respectively. In mediums with DE, the growth rates were slightly lower than using YE and reached $0.701 \mathrm{~h}^{-1}$ for $\mathrm{DE}_{\mathrm{A}}$ and $0.651 \mathrm{~h}^{-1}$ for $\mathrm{DE}_{\mathrm{B}}$. The biomass yield on the 14th day of cultivation in mediums containing $\mathrm{DE}_{\mathrm{A}}$ and $\mathrm{DE}_{\mathrm{B}}$, reached 0.234 and $0.221 \mathrm{~g} \cdot \mathrm{g}^{-1}$, respectively. 
Table 3. The medium compositions and the growth parameters of $C$. cohnii with extraction ethanol (EE) as carbon source.

\begin{tabular}{|c|c|c|c|c|c|c|c|c|}
\hline \multirow{2}{*}{ Medium } & \multicolumn{6}{|c|}{ Component, $\mathrm{g} \cdot \mathrm{L}^{-1}$} & \multirow{2}{*}{$\begin{array}{c}\mu_{\max } \\
h^{-1}\end{array}$} & \multirow{2}{*}{$\begin{array}{r}Y_{x / s} \\
g \cdot g^{-1}\end{array}$} \\
\hline & Sea Salts & $\mathrm{EE}$ & Ethanol & YE & $\mathrm{DE}_{\mathrm{A}}$ & $\mathrm{DE}_{\mathrm{B}}$ & & \\
\hline EE_YE & 12.5 & 5.9 & - & 1.0 & - & - & 0.757 & 0.282 \\
\hline EE_DE $\mathrm{A}$ & 12.5 & 5.9 & - & - & 1.0 & - & 0.701 & 0.234 \\
\hline EE_DE ${ }_{B}$ & 12.5 & 5.9 & - & - & - & 1.0 & 0.651 & 0.221 \\
\hline EE_DE & 12.5 & 5.9 & - & 0.25 & 0.75 & - & 0.658 & 0.238 \\
\hline EE_DE $E_{B 75}$ & 12.5 & 5.9 & - & 0.25 & - & 0.75 & 0.606 & 0.218 \\
\hline $\mathrm{EE}$ & 12.5 & 5.9 & - & - & - & - & 0.470 & 0.124 \\
\hline Ethanol & 12.5 & - & 4.7 & - & - & - & 0.383 & 0.122 \\
\hline
\end{tabular}

Where $\mu_{\max }$ is the specific biomass growth rate and $\mathrm{Y}_{\mathrm{x} / \mathrm{s}}$ is the biomass yield from a substrate.

From Figure 2 it can be observed that in the case of $\mathrm{YE}$ and $\mathrm{DE}_{\mathrm{A}}$, the specific biomass growth rate reached the maximum and remained constant until the 4th cultivation day until the substrate was not entirely consumed. In turn, the biomass growth rate in mediums containing only $\mathrm{DE}_{\mathrm{B}}$ was relatively high only on the first day of cultivation, after which it gradually decreased. It should be noted that during cultivation in mediums containing YE, similarly as in the glucose experiment, the lag phase was observed during the first day of cultivation.

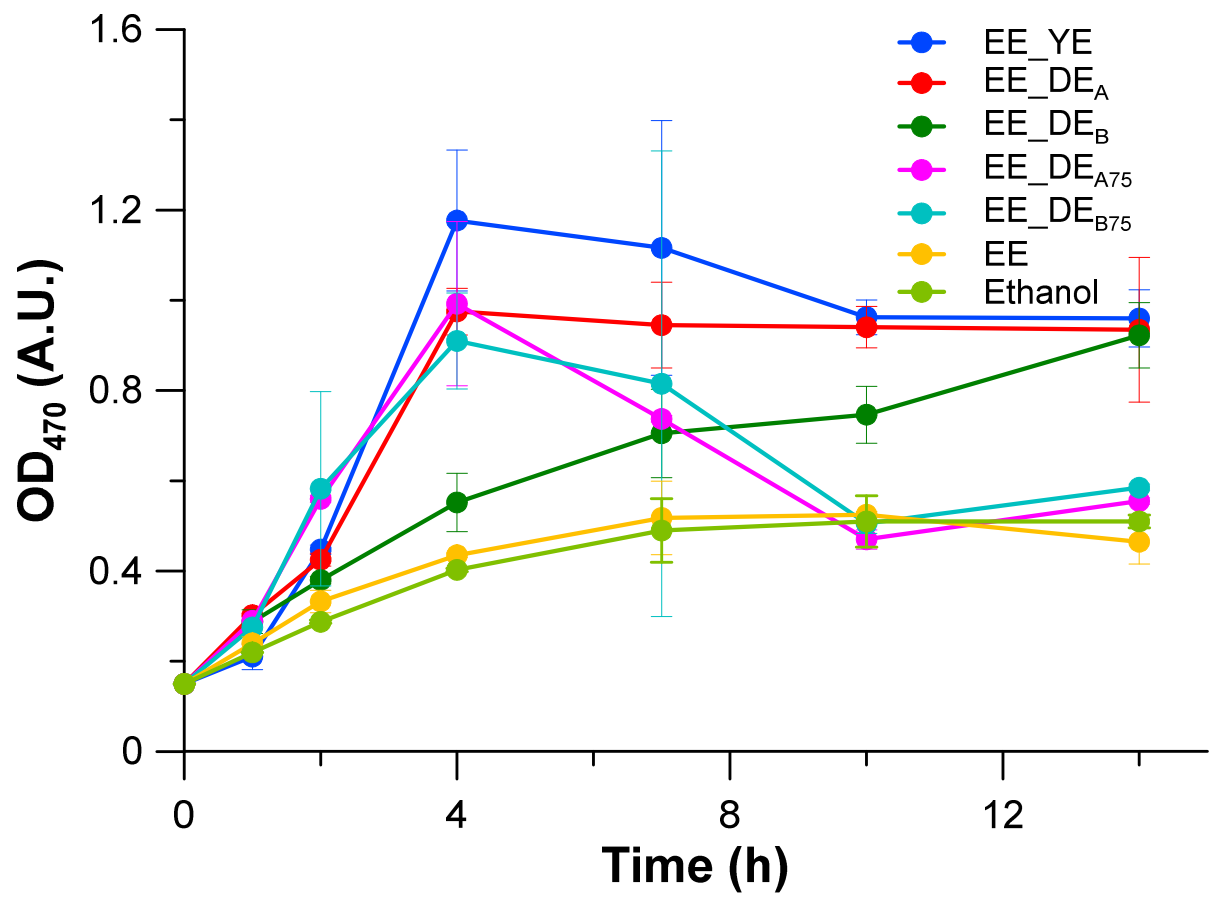

Figure 2. The optical density (OD) change over time of $C$. cohnii in mediums with extraction ethanol (EE) as a carbon source.

Experiments on pure and extraction ethanol (EE) were conducted to evaluate their effect on the biomass growth rate and yield. The specific growth rate in the case of EE was $0.470 \mathrm{~h}^{-1}$, which is for $20 \%$ more than in pure ethanol $\left(0.383 \mathrm{~h}^{-1}\right)$ and $50 \%$ more than in mediums containing YE or DE. The maximum biomass yield in both cases was very similar $\left(0.124 \mathrm{~g} \cdot \mathrm{g}^{-1}\right.$ for EE and $0.122 \mathrm{~g} \cdot \mathrm{g}^{-1}$ for pure ethanol), but with EE it was reached on the seventh day, and with pure ethanol on the 10th cultivation day. 


\subsection{Evaluation of Lipid/FA and PUFA Accumulation in C. cohnii Biomass by FTIR}

FTIR is a rapid method, particularly used for monitoring the relative content of each macromolecular component under varying growth conditions [28-31]. FTIR spectroscopy of $C$. cohnii biomass was used to evaluate the growth medium-induced production of lipids/FA and PUFAs. Fish oil supplements naturally contain about $30 \%$ of EPA and DHA in the form of triacylglycerols (TAGs), a tri-ester [32,33]. The FTIR spectrum of fish oil (Figure 3) reveals three high-intensity absorption bands at 2925, $2854 \mathrm{~cm}^{-1}\left(\mathrm{CH}_{3}\right.$ and $\mathrm{CH}_{2}$ vibrations, respectively), and $1745 \mathrm{~cm}^{-1}$ ( $\mathrm{C}=\mathrm{O}$ vibrations of lipid esters) that are indicative of lipids, FAs or triglycerides and therefore are indicative of total lipids. The spectrum also revealed a smaller peak at $3011 \mathrm{~cm}^{-1}$ (olefinic group $=\mathrm{CH}$ ), which is typical for unsaturated fatty acids (PUFAs/DHA) [34-39].

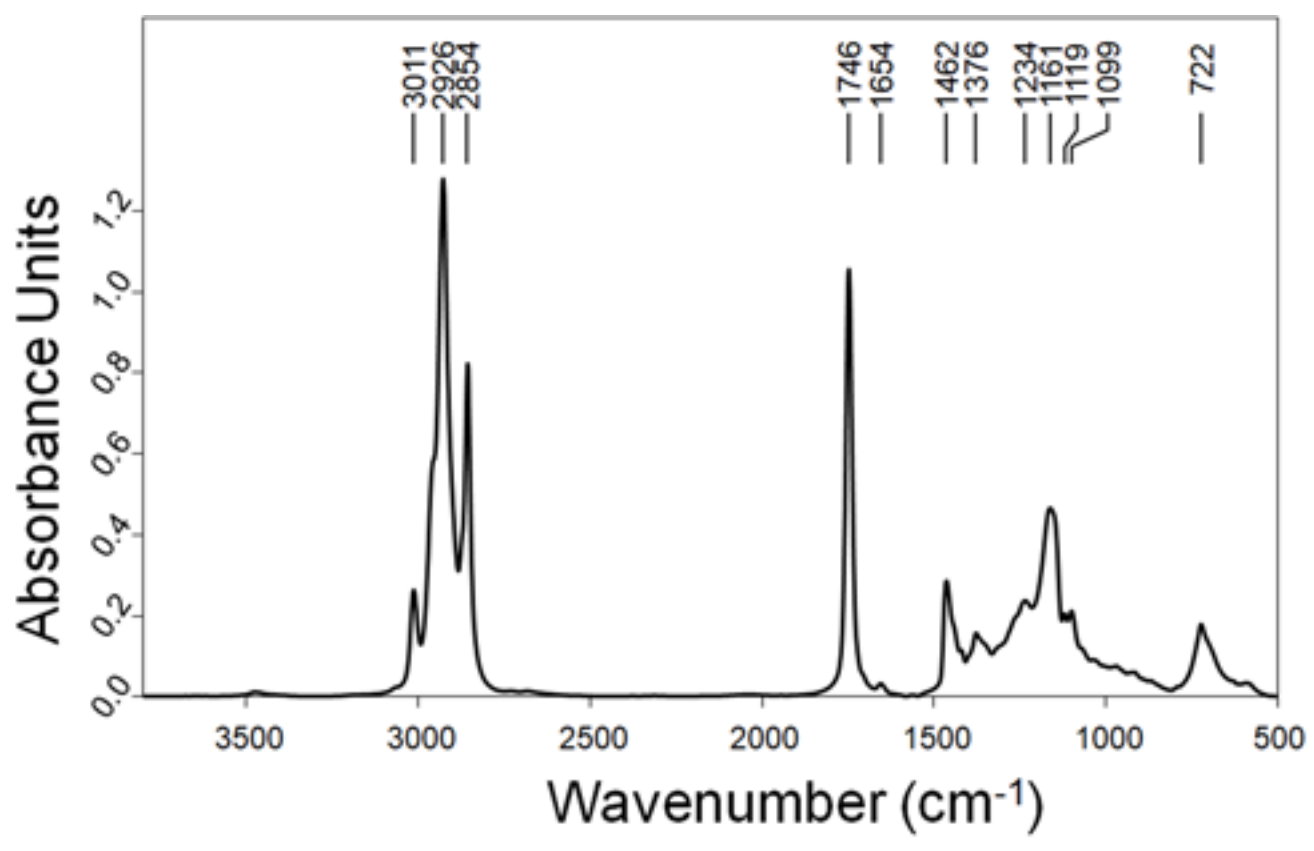

Figure 3. FTIR spectrum of fish oil food supplement (LYSI HF, Iceland). $10 \mathrm{~mL}$ contains: FA (2155 mg) incl. EPA (690 mg) and DHA (920 mg), and vitamins: E (9,2 mg), A (460 $\mu \mathrm{g})$, and D (20 $\mathrm{gg})$.

The characteristic absorption bands of the major cell components in the FTIR spectra are at $1080 \mathrm{~cm}^{-1}$ of carbohydrates; $1250 \mathrm{~cm}^{-1}$ of nucleic acids; 1650 and $1545 \mathrm{~cm}^{-1}$ of proteins (Amide I and Amide II, stretching vibrations of $\mathrm{C}=\mathrm{O}$ bond of amide and bending vibrations of the N-H bond, respectively); triplet bands in $2800-3000 \mathrm{~cm}^{-1}$ and $1744 \mathrm{~cm}^{-1}$ of lipids/FA (C-H stretching in $\mathrm{CH}_{3}$ and $\mathrm{CH}_{2}$ and $\mathrm{C}=\mathrm{O}$ of esters/ester carbonyl, respectively) and $\sim 3014 \mathrm{~cm}^{-1}$ of PUFAs /DHA (olefinic HC=CH stretching mode) $[28,40]$. The position and intensities of particular absorption bands allow to monitor or evaluate the macromolecular composition of cells as well as the accumulation of lipids/FAs and PUFAs [40-43]. PUFAs in the FTIR spectrum show a peak in the range of $3005-3013 \mathrm{~cm}^{-1}$, particularly the specific peak of DHA oils is at $3013,4 \mathrm{~cm}^{-1}$ [44].

Samples for FTIR were collected only on day 14, due to the amount of accumulated biomass in the experimental setup. For data analysis of $C$. cohnii cells, only spectra with absorption limits between 0.25 and 0.80 were used, and therefore, in accordance with the Lambert-Bouger-Beer law, the concentration of a component is proportional to the intensity of the absorption band. The spectra were vector normalized and therefore the intensity of the vibration band was proportional to the amount of band vibrations, i.e., the intensity is proportional to concentration. Therefore, the latter allows to crosscompare the cell biomass composition, accumulation, and number of macromolecular components (e.g., proteins, carbohydrates, FAs, PUFAs, DHA, etc). This is an especially 
valuable FTIR spectroscopy approach for quick and informative evaluation of large sample sets to select the best growth conditions for the production/accumulation of the targeted metabolites. Further quantitative and qualitative analyses of the most relevant samples can be carried out more precisely by FTIR spectroscopy, chromatography, mass spectroscopy, etc. Therefore, even though FTIR is a semi-quantitative method and does not provide precise values, it remarkably saves resources and time for evaluation of different biotechnological processes.

FTIR spectra of $C$. cohnii grown in mediums with $\mathrm{YE}, \mathrm{DE}_{\mathrm{A}}, \mathrm{DE}_{\mathrm{A} 75}, \mathrm{DE}_{\mathrm{B} 75}$, or glucose (Figure 4) showed that the macromolecular composition of cells is different depending on the growth medium composition. The spectrum profile of the C. cohnii cells grown in medium containing YE was noticeably different from others of this experimental set. Spectra of the cells grown with YE showed similar amounts of total carbohydrates but higher content of proteins and lower content of total lipids than in cells grown in mediums with $\mathrm{DE}_{\mathrm{A}}, \mathrm{DE}_{\mathrm{A} 75} \mathrm{DE}_{\mathrm{B} 75}$, or glucose. The vector normalized spectra of cells grown without YE showed similar content of the total carbohydrates and proteins, but the content of lipids/FA and PUFAs/DHA varied. The highest number of total lipids/FAs (2925, 2854, and $1745 \mathrm{~cm}^{-1}$ ) was detected in cells grown in mediums with glucose but lower with $\mathrm{DE}_{\mathrm{A} 75}$ and $\mathrm{DE}_{\mathrm{B} 75}$. However, a higher amount of PUFAs/DHA $\left(3014 \mathrm{~cm}^{-1}\right)$ was detected in cells grown in medium with $\mathrm{DE}_{\mathrm{A} 75}$.

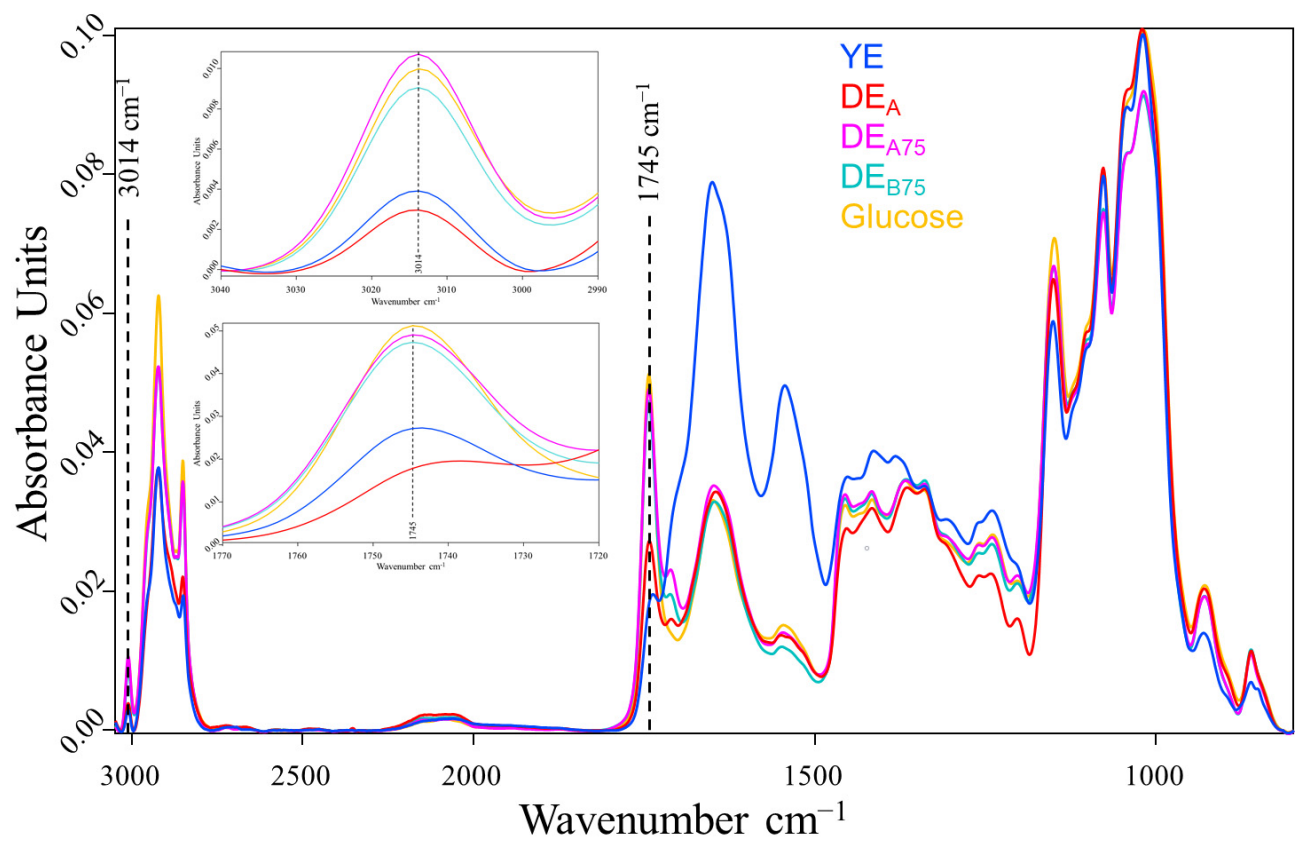

Figure 4. Vector normalized FTIR spectra of $C$. cohnii biomass after 14 days of growth in mediums, with $\mathrm{YE}, \mathrm{DE}_{\mathrm{A}}, \mathrm{DE}_{\mathrm{A} 75}, \mathrm{DE}_{\mathrm{B} 75}$, or glucose.

FTIR spectra of $C$. cohnii cultivated in mediums with EE-YE, EE-DE $\mathrm{A}_{\mathrm{A}}, \mathrm{EE}^{\mathrm{D}} \mathrm{DE}_{\mathrm{B}}, \mathrm{EE}-$ $\mathrm{DE}_{\mathrm{A} 75}, \mathrm{EE}-\mathrm{DE}_{\mathrm{B} 75}, \mathrm{EE}$, or pure ethanol are shown in Figure 5. FTIR spectra showed different cell macromolecular compositions, which can be grouped into two clusters. The first group EE-YE, EE-DE ${ }_{\mathrm{A} 75}$, and EE-DE $\mathrm{B}_{\mathrm{B} 5}$ produce relatively high amounts of proteins, low amounts of total carbohydrates, and lesser amounts of total lipids than cells grown with EE-DE $\mathrm{A}_{\mathrm{A}}$ EE-DE $E_{B}, E E$, or pure ethanol. The FTIR spectra of the second group (i.e., cells grown in $\mathrm{EE}_{\mathrm{DE}}, \mathrm{EE}_{\mathrm{A}}, \mathrm{DE} \mathrm{B}_{\mathrm{B}}, \mathrm{EE}$, or pure ethanol showed more total lipids/FA and PUFAs/DHA compared to those of the first group). The highest content of FAs and PUFAs/DHA was

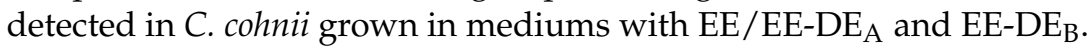




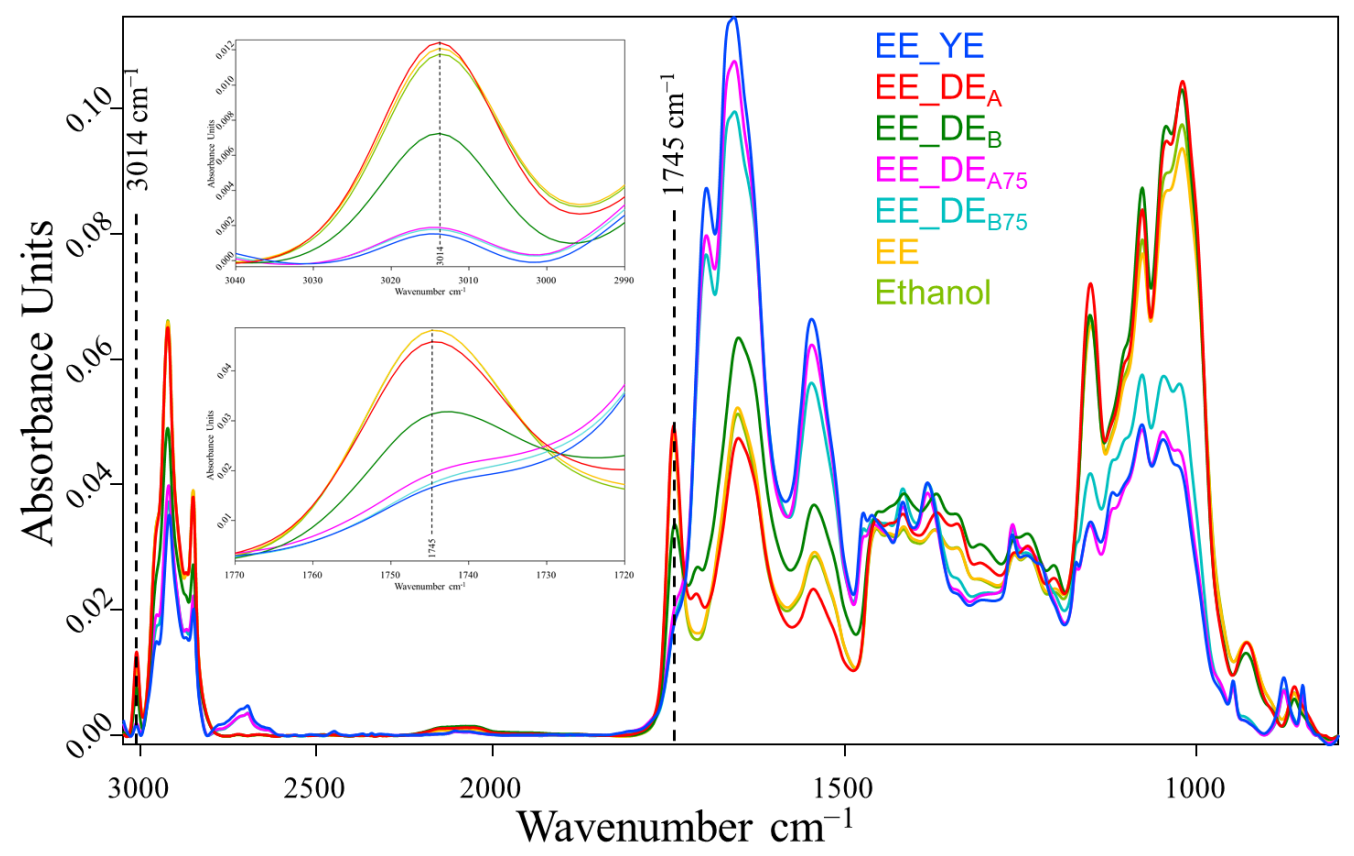

Figure 5. Vector normalized FTIR spectra of C. cohnii biomass after 14 days of growth in seven different mediums with ethanol.

\section{Discussion}

The main components of the culture medium for C. cohnii are the substrate (glucose, glycerol, ethanol, acetic acid), yeast extract, and sea salt (artificial or natural). The biomass yield from each component of the cultivation medium was determined during bioreactor cultivations and reached $0.7 \mathrm{~g} \cdot \mathrm{g}^{-1}$ for glucose, $5.3 \mathrm{~g} \cdot \mathrm{g}^{-1}$ for yeast extract, and $0.87 \mathrm{~g} \cdot \mathrm{g}^{-1}$ for sea salt (results not shown). Despite the fact that, compared to other components, a small amount (in terms of mass) of yeast extract is used, its price is the highest (8-10 USD $/ \mathrm{kg}$ ) and makes up more than half of the cultivation medium cost. Considering that the costs of raw materials for the production of SCO is about half of all production expenses, the reduction of the necessary amounts of cultivation medium components poses a significant effect on the overall process economy.

The obtained results of this study show that $\mathrm{DE}_{\mathrm{A}}$ stimulated a similar biomass growth rate when compared to $\mathrm{YE}$, while the biomass yield was significantly higher if glucose was used as a carbon source. The absence of a lag phase during cultivation in mediums containing only $\mathrm{DE}_{\mathrm{A}}$, both with glucose or ethanol, unlike mediums with $\mathrm{YE}$, indicates that the mineral and vitamin composition of $\mathrm{DE}_{\mathrm{A}}$ is more preferable for proliferation of $C$. cohnii cells. However, a decrease of the biomass growth rate in mediums with $\mathrm{DE}_{\mathrm{A}}$ should be noted. The increase in biomass titres after cultivation for four days (media with $\mathrm{DE}_{\mathrm{A}}$ ) and seven days (media with $\mathrm{DE}_{\mathrm{A} 75}$ ) becomes constant and equal to that obtained in the control medium (with glucose). Therefore, despite the high initial biomass growth rates, the efficiency of $\mathrm{DE}_{\mathrm{A}}$ is approximately two times lower when compared to that of $\mathrm{YE}$. The latter can be compensated by increasing the initial concentrations of $\mathrm{DE}_{\mathrm{A}}$ or the addition of small amounts of YE to the cultivation medium, which in itself depends on the economic feasibility of the process.

The use of $\mathrm{DE}_{\mathrm{B}}$ as a nitrogen source, in the case of both glucose and ethanol, had a minimal effect on the growth rate and biomass yield. Obviously, many thermal and chemical biomass processing steps, which are necessary to obtain $\mathrm{DE}_{\mathrm{B}}$, completely or to a larger extent degrade the initial vitamins present in C. cohnii biomass.

$\mathrm{EE}$, although it did not significantly affect the biomass growth rate, showed the same biomass yield when compared to the control sample (pure ethanol), which indicates the feasibility of using it as a carbon source for $C$. cohnii cultivation. 
Cross comparison of the FTIR spectral data showed that the growth medium components clearly affect the biochemical composition of $C$. cohnii cells. When grown in mediums with YE, EE-YE, EE-DE ${ }_{\mathrm{A} 75}$, or EE-DE ${ }_{\mathrm{B} 75}, \mathrm{C}$. cohnii cells contained more proteins (compared to the cells grown in any other studied mediums) but the absorption band at $1745 \mathrm{~cm}^{-1}$ (ester $\mathrm{C}=\mathrm{O}$ bonds of lipids/FA) was not detected, thus indicating that the cells did not overproduce lipids/FA. In the context of searching for the growth conditions promoting the accumulation of PUFAs/DHA the most promising results were acquired when C. cohnii was cultivated in the mediums with $\mathrm{DE}_{\mathrm{A} 75}$ and glucose (Figure 4), EE-DE $\mathrm{A}_{\mathrm{A}}, \mathrm{EE}-\mathrm{DE} \mathrm{B}_{\mathrm{B}}, \mathrm{EE}$, or ethanol (Figure 5). However, further quantitative analyses of the main cell macromolecular components (carbohydrates, proteins, and lipids) are needed to identify the most efficient growth media that promotes the overproduction of PUFAs/DHA by C. cohnii.

To summarize the above mentioned, $\mathrm{DE}_{\mathrm{A}}$ and $\mathrm{EE}$ can both be successfully used as alternative sources of nitrogen, nutrients, and carbon to reduce the costs of conventional $\mathrm{SCO}$ and DHA production processes.

Moreover, the production of $\mathrm{DE}_{\mathrm{A}}$ can be optimized through the use of hydrochloric acid and sodium hydroxide. The hydrolysate obtained in this way, after neutralization with acid, can be directly used to create a suitable dinoflagellate cultivation medium. Furthermore, the use of the above-mentioned hydrolysate will make it possible to exclude such energy-demanding steps of the production process as evaporation and simultaneously significantly reduce the amount of sea salt, which otherwise should be added in the cultivation medium in large quantities.

\section{Materials and Methods}

\subsection{Cultivation Conditions}

Crypthecodinium cohnii CCMP 316 was obtained from the Provasoli-Guillard National Center for Marine Algae and Microbiota (NCMA) (USA). The culture inoculum was grown in a custom-made setup (see Scheme 3) consisting of $250 \mathrm{~mL}$ bottles with a working volume of $150 \mathrm{~mL}$. The growth medium containing glucose $5 \mathrm{~g} \cdot \mathrm{L}^{-1}$, yeast extract $2 \mathrm{~g} \cdot \mathrm{L}^{-1}$ and sea salts $25 \mathrm{~g} \cdot \mathrm{L}^{-1}$, with aeration $30 \mathrm{~mL} / \mathrm{min}$, rotation speed $130 \mathrm{rpm}$ (provided by an orbital shaker PSU-20i, Biosan, Riga, Latvia) was maintained at $25^{\circ} \mathrm{C}$. The cultivation medium compositions for experiments are shown in Table 4, as well as in Tables 2 and 3. The initial optical density $\left(\mathrm{OD}_{470}\right)$ of experiments was set to 0.15 .

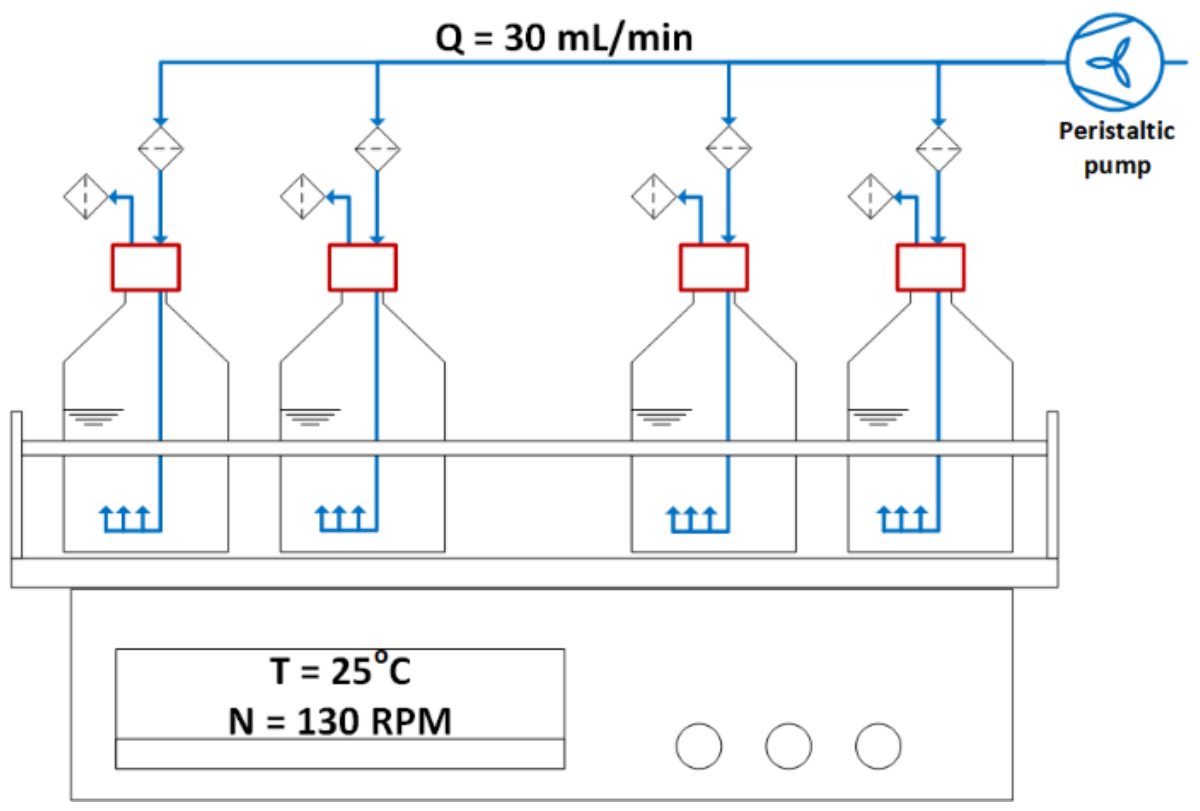

Scheme 3. C. cohnii cultivation experiment setup. 
Table 4. The medium compositions for C. cohnii cultivations.

\begin{tabular}{|c|c|c|c|c|c|c|c|}
\hline \multirow{2}{*}{ Medium } & \multicolumn{7}{|c|}{ Component, $\mathrm{g} \cdot \mathrm{L}^{-1}$} \\
\hline & Sea Salts & Glucose & EE & Ethanol & YE & $\mathrm{DE}_{\mathrm{A}}$ & $\mathrm{DE}_{\mathrm{B}}$ \\
\hline YE & 12.5 & 10.0 & - & - & 1.0 & - & - \\
\hline $\mathrm{DE}_{\mathrm{A}}$ & 12.5 & 10.0 & - & - & - & 1.0 & - \\
\hline $\mathrm{DE}_{\mathrm{B}}$ & 12.5 & 10.0 & - & - & - & - & 1.0 \\
\hline $\mathrm{DE}_{\mathrm{A} 75}$ & 12.5 & 10.0 & - & - & 0.25 & 0.75 & - \\
\hline $\mathrm{DE}_{\mathrm{B} 75}$ & 12.5 & 10.0 & - & - & 0.25 & - & 0.75 \\
\hline Glucose & 12.5 & 10.0 & - & - & - & - & - \\
\hline EE_YE & 12.5 & - & 5.9 & - & 1.0 & - & - \\
\hline EE_DE & 12.5 & - & 5.9 & - & - & 1.0 & - \\
\hline EE_DE & 12.5 & - & 5.9 & - & - & - & 1.0 \\
\hline EE_DE $\mathrm{A75}$ & 12.5 & - & 5.9 & - & 0.25 & 0.75 & - \\
\hline EE_DE & 12.5 & - & 5.9 & - & 0.25 & - & 0.75 \\
\hline EE & 12.5 & - & 5.9 & - & - & - & - \\
\hline Ethanol & 12.5 & - & - & 4.7 & - & - & - \\
\hline
\end{tabular}

\subsection{Dinoflagellate Extract and Extraction Ethanol Obtainment}

Dinoflagellate extracts (DEs) were obtained by recycling de-oiled C. cohnii biomass from the cultivation process in a laboratory scale bioreactor EDF-5.4_1 (JSC Biotehniskais centrs, Riga, Latvia) by a method adapted from Gao et al. [45]. The de-oiled biomass was hydrolysed with $\mathrm{H}_{2} \mathrm{SO}_{4}$ at $121^{\circ} \mathrm{C}$ for $20 \mathrm{~min}$. The hydrolysed solution was neutralized with an appropriate amount of $\mathrm{CaCO}_{3}$. The solid fraction was separated from the hydrolysate by filtration. Most of the liquid hydrolysate was evaporated by heating at $120^{\circ} \mathrm{C}, 600 \mathrm{rpm}$. The remaining moisture was evaporated by drying the sample in an oven at $80^{\circ} \mathrm{C}$ overnight. The obtained dry extract pellets were grinned into a fine powder, hereinafter referred to as DE. De-oiled biomass for $\mathrm{DE}_{\mathrm{A}}$ obtainment was produced by a method adapted from Halim et al. [46]. Lipids were extracted from lyophilized biomass with the use of Soxhlet extraction with hexane as the solvent, containing $0.01 \%$ butylated hydroxytoluene (BHT). De-oiled biomass for $\mathrm{DE}_{\mathrm{B}}$ obtainment was produced by a method adapted from Mendes et al. [47]. Lipids were extracted with hexane (BHT concentration in hexane $0.01 \%$ ) from the wet biomass, followed by incubation overnight at $20^{\circ} \mathrm{C}$ with ethanol and $\mathrm{KOH}$, simultaneously the extraction ethanol (EE) was obtained and separated. The acidification with $\mathrm{HCl}$ and additional hexane extractions were performed, the resulting suspension was used for DE obtainment as described above.

\subsection{Optical Density and Glucose Concentration Measurements}

C. cohnii growth was monitored via optical density (OD) measurements at a wavelength of $470 \mathrm{~nm}$ with a spectrophotometer Jenway 6300 (Cole-Parmer, Saint Neots, UK). The glucose concentration was measured enzymatically with an AccuChek ACTIVE blood sugar analyzer (Roche, Basel, Switzerland). Samples for OD and glucose measurements were taken on days $1,2,4,7,10$, and 14 . The experiments were performed in at-least triplicate and the experimental data was expressed as mean \pm standard deviation (SD).

\subsection{Determination of Biomass Dry Cell Weight}

The biomass dry cell weight (DCW) in relation to the absorbance at a wavelength of $470 \mathrm{~nm}$ was determined gravimetrically as described in [48]. During the present study, the correlation coefficients value was determined as $1.415 \mathrm{~g}(\mathrm{DCW}) \cdot \mathrm{L}^{-1} \cdot$ A.U. ${ }^{-1}$. 


\subsection{Fourier Transform Infrared Spectroscopy}

Fourier transform infrared (FTIR) spectra of biomass were recorded using Vertex 70 coupled with the HTS XT microplate reader (Bruker Optik GmbH, Ettlingen, Germany) Sample aliquots were pipetted on a 384 well microplate dried and recorded in the frequency range of 4000-600 $\mathrm{cm}^{-1}$. Omega fatty acids were identified by absorption bands at $\sim 1743 \mathrm{~cm}^{-1}$ and $\sim 3012 \mathrm{~cm}^{-1}$. Due to the experimental setup and amount of accumulated biomass during the cultivation processes, samples for FTIR were collected only on day 14

For data analyses only spectra with absorption limits between 0.25 and 0.80 were used, and therefore, in accordance with the Lambert-Bouger-Beer law, the concentration of a component is proportional to the intensity of the absorption band. Spectra were vector normalized, and therefore the intensity of the vibration band was proportional to the amount of band vibrations (i.e., the intensity is proportional to concentration).

\section{Conclusions}

FTIR spectra of $C$. cohnii cells clearly showed the medium-induced metabolic responses, including variations of the produced total lipids/FA, PUFAs, and DHA. Further studies of the concentrations and composition of PUFAs produced under various cultivation conditions together with the cell growth data would allow us to identify the most efficient cultivation medium composition. Nevertheless, current observations point out to the positive effect (both in terms of process economy and process efficiency) of supplementing the standard C. cohnii cultivation medium with recycled components (e.g., dinoflagellate extracts and extraction ethanol).

Author Contributions: Conceptualization, K.D. and E.D.; methodology, E.D., M.G. and A.S. (Anastasija Suleiko); formal analysis, K.D.; investigation, E.D., M.G., K.S. and A.S. (Anastasija Suleiko); resources, J.V.; writing-original draft preparation, E.D.; writing-review and editing, K.D., A.S. (Arturs Suleiko), A.S. (Anastasija Suleiko), M.G., J.V. and E.D.; visualization, A.S. (Arturs Suleiko), K.D. and K.S.; supervision, K.D. All authors have read and agreed to the published version of the manuscript.

Funding: This research was funded by European Regional Development Fund, grant number 1.1.1.1/18/A/022.

Institutional Review Board Statement: Not applicable.

Conflicts of Interest: The authors declare no conflict of interest.

\section{References}

1. Adarme-Vega, T.C.; Thomas-Hall, S.R.; Schenk, P.M. Towards sustainable sources for omega-3 fatty acids production. Curr. Opin. Biotechnol. 2014, 26, 14-18. [CrossRef] [PubMed]

2. Stramarkou, M.; Oikonomopoulou, V.; Chalima, A.; Boukouvalas, C.; Topakas, E.; Krokida, M. Optimization of green extractions for the recovery of docosahexaenoic acid (DHA) from Crypthecodinium cohnii. Algal Res. 2021, 58, 102374. [CrossRef]

3. da Silva, T.L.; Moniz, P.; Silva, C.; Reis, A. The dark side of microalgae biotechnology: A heterotrophic biorefinery platform directed to $\omega-3$ rich lipid production. Microorganisms 2019, 7, 670. [CrossRef] [PubMed]

4. Taborda, T.; Moniz, P.; Reis, A.; da Silva, T.L. Evaluating low-cost substrates for Crypthecodinium cohnii lipids and DHA production, by flow cytometry. J. Appl. Phycol. 2021, 33, 263-274. [CrossRef]

5. Ji, X.-J.; Ren, L.-J.; Huang, H. Omega-3 Biotechnology: A Green and Sustainable Process for Omega-3 Fatty Acids Production. Front. Bioeng. Biotechnol. 2015, 3, 190-209. [CrossRef]

6. Sharma, J.; Sarmah, P.; Bishnoi, N.R. Market Perspective of EPA and DHA Production from Microalgae. In Nutraceutical Fatty Acids from Oleaginous Microalgae; Scrivener Publishing LLC: Beverly, MA, USA, 2020; pp. 281-297. [CrossRef]

7. Braunwald, T.; French, W.T.; Claupein, W.; Graeff-Hönninger, S. Economic assessment of microbial biodiesel production using heterotrophic yeasts. Int. J. Green Energy 2016, 13, 274-282. [CrossRef]

8. Jovanovic, S.; Dietrich, D.; Becker, J.; Kohlstedt, M.; Wittmann, C. Microbial production of polyunsaturated fatty acids-high-value ingredients for aquafeed, superfoods, and pharmaceuticals. Curr. Opin. Biotechnol. 2021, 69, 199-211. [CrossRef]

9. Petrie, J.R.; Shrestha, P.; Zhou, X.R.; Mansour, M.P.; Liu, Q.; Belide, S.; Nichols, P.D.; Singh, S.P. Metabolic Engineering Plant Seeds with Fish Oil-Like Levels of DHA. PLoS ONE 2012, 7, 2-8. [CrossRef] [PubMed]

10. Santos-Sánchez, N.F.; Valadez-Blanco, R.; Hernández-Carlos, B.; Torres-Ariño, A.; Guadarrama-Mendoza, P.C.; Salas-Coronado, R. Lipids rich in $\omega-3$ polyunsaturated fatty acids from microalgae. Appl. Microbiol. Biotechnol. 2016, 100, 8667-8684. [CrossRef] 
11. Graham, I.A.; Larson, T.; Napier, J.A. Rational metabolic engineering of transgenic plants for biosynthesis of omega-3 polyunsaturates. Curr. Opin. Biotechnol. 2007, 18, 142-147. [CrossRef]

12. Mendes, A.; Reis, A.; Vasconcelos, R.; Guerra, P.; Lopes Da Silva, T. Crypthecodinium cohnii with emphasis on DHA production: A review. J. Appl. Phycol. 2009, 21, 199-214. [CrossRef]

13. Xiao, R.; Li, X.; Zheng, Y. Comprehensive Study of Cultivation Conditions and Methods on Lipid Accumulation of a Marine Protist, Thraustochytrium striatum. Protist 2018, 169, 451-465. [CrossRef]

14. Lv, M.; Wang, F.; Zeng, L.; Bi, Y.; Cui, J.; Liu, L.; Bi, Y.; Chen, L.; Zhang, W. Identification and metabolomic analysis of a starchdeficient Crypthecodinium cohnii mutant reveals multiple mechanisms relevant to enhanced growth and lipid accumulation. Algal Res. 2020, 50, 102001. [CrossRef]

15. Rumiani, L.A.; Jalili, H.; Amrane, A. Enhanced docosahexaenoic acid production by Crypthecodinium cohnii under combined stress in two-stage cultivation with date syrup based medium. Algal Res. 2018, 34, 75-81. [CrossRef]

16. Paz, A.; Karnaouri, A.; Templis, C.C.; Papayannakos, N.; Topakas, E. Valorization of exhausted olive pomace for the production of omega-3 fatty acids by Crypthecodinium cohnii. Waste Manag. 2020, 118, 435-444. [CrossRef]

17. De Swaaf, M.E.; Sijtsma, L.; Pronk, J.T. High-cell-density fed-batch cultivation of the docosahexaenoic acid producing marine alga Crypthecodinium cohnii. Biotechnol. Bioeng. 2003, 81, 666-672. [CrossRef]

18. De Swaaf, M.E.; Pronk, J.T.; Sijtsma, L. Fed-batch cultivation of the docosahexaenoic-acid-producing marine alga Crypthecodinium cohnii on ethanol. Appl. Microbiol. Biotechnol. 2003, 61,40-43. [CrossRef]

19. de Swaaf, M.E.; de Rijk, T.C.; Eggink, G.; Sijtsma, L. Optimisation of docosahexaenoic acid production in batch cultivations by Crypthecodinium cohnii. Prog. Ind. Microbiol. 1999, 35, 185-192. [CrossRef]

20. Karnaouri, A.; Asimakopoulou, G.; Kalogiannis, K.G.; Lappas, A.A.; Topakas, E. Efficient production of nutraceuticals and lactic acid from lignocellulosic biomass by combining organosolv fractionation with enzymatic/fermentative routes. Bioresour. Technol. 2021, 341, 125846. [CrossRef] [PubMed]

21. Chalima, A.; Taxeidis, G.; Topakas, E. Optimization of the production of docosahexaenoic fatty acid by the heterotrophic microalga Crypthecodinium cohnii utilizing a dark fermentation effluent. Renew. Energy 2020, 152, 102-109. [CrossRef]

22. Safdar, W.; Shamoon, M.; Zan, X.; Haider, J.; Sharif, H.R.; Shoaib, M.; Song, Y. Growth kinetics, fatty acid composition and metabolic activity changes of Crypthecodinium cohnii under different nitrogen source and concentration. AMB Express 2017, 7, 85. [CrossRef]

23. Safdar, W.; Zan, X.; Shamoon, M.; Sharif, H.R.; Mukama, O.; Tang, X.; Song, Y. Effects of twenty standard amino acids on biochemical constituents, docosahexaenoic acid production and metabolic activity changes of Crypthecodinium cohnii. Bioresour. Technol. 2017, 238, 738-743. [CrossRef] [PubMed]

24. Jiang, Y.; Chen, F.; Liang, S.Z. Production potential of docosahexaenoic acid by the heterotrophic marine dinoflagellate Crypthecodinium cohnii. Process Biochem. 1999, 34, 633-637. [CrossRef]

25. Gong, Y.; Liu, J.; Jiang, M.; Liang, Z.; Jin, H.; Hu, X.; Wan, X.; Hu, C. Improvement of omega-3 docosahexaenoic acid production by marine dinoflagellate Crypthecodinium cohnii using rapeseed meal hydrolysate and waste molasses as feedstock. PLoS ONE 2015, 10, e0125368. [CrossRef]

26. Jiang, Y.; Chen, F. Effects of medium glucose concentration and pH on docosahexaenoic acid content of heterotrophic Crypthecodinium cohnii. Process Biochem. 2000, 35, 1205-1209. [CrossRef]

27. Diao, J.; Song, X.; Zhang, X.; Chen, L.; Zhang, W. Genetic Engineering of Crypthecodinium cohnii to increase growth and lipid accumulation. Front. Microbiol. 2018, 9, 492. [CrossRef] [PubMed]

28. Grube, M.; Bekers, M.; Upite, D.; Kaminska, E. IR-spectroscopic studies of Zymomonas mobilis and levan precipitate. Vib. Spectrosc. 2002, 28, 277-285. [CrossRef]

29. Fuchino, K.; Kalnenieks, U.; Rutkis, R.; Grube, M.; Bruheim, P. Metabolic profiling of glucose-fed metabolically active resting Zymomonas mobilis strains. Metabolites 2020, 10, 81. [CrossRef]

30. Grube, M.; Kalnenieks, U.; Muter, O. Metabolic response of bacteria to elevated concentrations of glyphosate-based herbicide. Ecotoxicol. Environ. Saf. 2019, 173, 373-380. [CrossRef]

31. Grube, M.; Shvirksts, K.; Krafft, C.; Kokorevicha, S.; Zandberga, E.; Abols, A.; Line, A.; Kalnenieks, U. Miniature diamond-anvil cells for FTIR-microspectroscopy of small quantities of biosamples. Analyst 2018, 143, 3595-3599. [CrossRef]

32. Killeen, D.P.; Marshall, S.N.; Burgess, E.J.; Gordon, K.C.; Perry, N.B. Raman Spectroscopy of Fish Oil Capsules: Polyunsaturated Fatty Acid Quantitation Plus Detection of Ethyl Esters and Oxidation. J. Agric. Food Chem. 2017, 65, 3551-3558. [CrossRef]

33. Karunathilaka, S.R.; Choi, S.H.; Mossoba, M.M.; Yakes, B.J.; Brückner, L.; Ellsworth, Z.; Srigley, C.T. Rapid classification and quantification of marine oil omega-3 supplements using ATR-FTIR, FT-NIR and chemometrics. J. Food Compos. Anal. 2019, 77, 9-19. [CrossRef]

34. Guillén, M.D.; Cabo, N. Characterization of edible oils and lard by fourier transform infrared spectroscopy. Relationships between composition and frequency of concrete bands in the fingerprint region. JAOCS J. Am. Oil Chem. Soc. 1997, 74, 1281-1286. [CrossRef]

35. Dean, A.P.; Sigee, D.C.; Estrada, B.; Pittman, J.K. Using FTIR spectroscopy for rapid determination of lipid accumulation in response to nitrogen limitation in freshwater microalgae. Bioresour. Technol. 2010, 101, 4499-4507. [CrossRef] 
36. Vongsvivut, J.; Heraud, P.; Zhang, W.; Kralovec, J.A.; McNaughton, D.; Barrow, C.J. Quantitative determination of fatty acid compositions in micro-encapsulated fish-oil supplements using Fourier transform infrared (FTIR) spectroscopy. Food Chem. 2012, 135, 603-609. [CrossRef] [PubMed]

37. Ferreira, R.; Lourenço, S.; Lopes, A.; Andrade, C.; Câmara, J.S.; Castilho, P.; Perestrelo, R. Evaluation of fatty acids profile as a useful tool towards valorization of by-products of agri-food industry. Foods 2021, 10, 2867. [CrossRef] [PubMed]

38. Ripoche, A.; Guillard, A.S. Determination of fatty acid composition of pork fat by Fourier transform infrared spectroscopy. Meat Sci. 2001, 58, 299-304. [CrossRef]

39. Meng, W.; Jiang, Y.; Rothschild, D.; Lipke, M.; Hall, G.; Wang, L. Modeling the structure and infrared spectra of omega-3 fatty acid esters. J. Chem. Phys. 2020, 153. [CrossRef] [PubMed]

40. Ami, D.; Posteri, R.; Mereghetti, P.; Porro, D.; Doglia, S.M.; Branduardi, P. Fourier transform infrared spectroscopy as a method to study lipid accumulation in oleaginous yeasts. Biotechnol. Biofuels 2014, 7, 12. [CrossRef]

41. Berzins, K.; Muiznieks, R.; Baumanis, M.R.; Strazdina, I.; Shvirksts, K.; Prikule, S.; Galvanauskas, V.; Pleissner, D.; Pentjuss, A.; Grube, M.; et al. Kinetic and stoichiometric modeling based analysis of docosahexaenoic acid (DHA) production potential by C.cohnii from glycerol, glucose and ethanol. Mar. Drugs 2022. Under review.

42. Shapaval, V.; Afseth, N.K.; Vogt, G.; Kohler, A. Fourier transform infrared spectroscopy for the prediction of fatty acid profiles in Mucor fungi grown in media with different carbon sources. Microb. Cell Fact. 2014, 13, 1-11. [CrossRef]

43. Vongsvivut, J.; Heraud, P.; Gupta, A.; Puri, M.; McNaughton, D.; Barrow, C.J. FTIR microspectroscopy for rapid screening and monitoring of polyunsaturated fatty acid production in commercially valuable marine yeasts and protists. Analyst 2013, 138, 6016-6031. [CrossRef]

44. Yoshida, S.; Yoshida, H. Noninvasive analyses of polyunsaturated fatty acids in human oral mucosa in vivo by fourier-transform infrared spectroscopy. Biopolymers 2004, 74, 403-412. [CrossRef] [PubMed]

45. Gao, M.-T.; Shimamura, T.; Ishida, N.; Takahashi, H. Investigation of utilization of the algal biomass residue after oil extraction to lower the total production cost of biodiesel. J. Biosci. Bioeng. 2012, 114, 330-333. [CrossRef] [PubMed]

46. Halim, R.; Danquah, M.K.; Webley, P.A. Extraction of oil from microalgae for biodiesel production: A review. Biotechnol. Adv. 2012, 30, 709-732. [CrossRef] [PubMed]

47. Mendes, A.; Da Silva, T.L.; Reis, A. DHA concentration and purification from the marine heterotrophic microalga Crypthecodinium cohnii CCMP 316 by winterization and urea complexation. Food Technol. Biotechnol. 2007, 45, 38-44.

48. Dubencovs, K.; Liepins, J.; Suleiko, A.; Suleiko, A.; Vangravs, R.; Kassaliete, J.; Scerbaka, R.; Grigs, O. Optimization of synthetic media composition for Kluyveromyces marxianus fed-batch cultivation. Fermentation 2021, 7, 62. [CrossRef] 